\title{
The New Department of Zoology of the University of Edinburgh.
}

GOR many years past the accommodation in the Department of Zoology at Edinburgh has been inadequate to meet modern needs and to cope with the number of students studying the subject. In 1923 the late Mr. Laurence Pullar, of Bridge of Earn, visited the Department and was deeply impressed with the adverse conditions he found. Mr. Pullar,

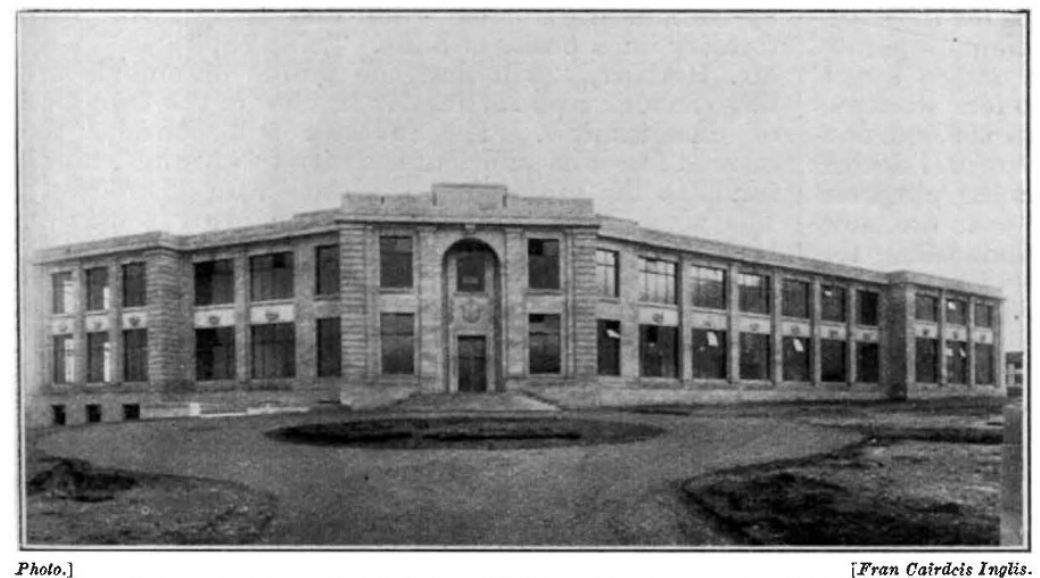

Fig. 1.-The new Department of Zoology of the University of Edinburgh.

permission as the King's Buildings, and Prince George expressed his pleasure at learning that through the munificence of various donors, private and corporate, other buildings were soon to be erected on the same site, forming part of a scheme for the expansion of the University. He congratulated the architects upon their success in combining pleasing effect with utility. After the opening, Prince George was invested with the honorary degree of Doctor of Laws, made a tour of inspection, and attended a luncheon in the Old University buildings. The University O.T.C. mounted a guard of honour.

The new building (Fig. 1) is of sandstone from the Blaxter quarry, and consists of a central part with a larger wing facing north and a smaller one facing north-east: its total length is 287 feet. Tt is two. storied for the greater part, but the fall of the ground allows of a welllit 'basement' under the east wing. Between the large windows in the upper and lower stories are a number of panels with oval medallions about $4 \mathrm{ft}$. 6 in. long bearing representations of a series of animals. They are arranged in sequence

who had long been sympathetically interested in zoology, more particularly in those branches of it that occupied the attention of his friend the late Sir John Murray, made a donation of $£ 20,000$ towards the erection of new laboratories. His much-appreciated gift remained anonymous until shortly before his death in 1926. In the same year the Trustees of the Carnegie Trust for the Universities of Scotland, in their allocation of grants for the quinquennium $1925-30$, set aside a sum of $£ 18,000$.

Prof. Augustus Trowbridge, of Princeton University, then director for Europe of the International Education Board, paid an unannounced visit to the Department in 1926 and inquired into its needs and financial position. As a result of this, and with his sympathetic co-operation, Prof. J. H. Ashworth was enabled to draw up a statement of the require. ments. The Board saw its way to give $£ 74,000$ for the completion of a building, for equipment, endowment, and addition to staff and technicians.

Prof. Ashworth drew up sketch plans which were placed in the hands of Sir Robert Lorimer and Mr. J. Matthew, and work was commenced in June 1927. The building was formally opened by H.P.H. Prince George on May 15 last in the presence of the ViceChancellor, a large number of representatives of the national and civic authorities, and of zoologists from other universities. In his speech, Prince George referred to the traditions of the Department, the chair of which was founded in 1770, and to the importance of zoology and its many applications to the welfare not only of Great Britain, but of the whole Empire. The need for trained zoologists, particularly overseas, at the present time is great. The building is the second of a new group known by and chosen to represent the main zoogeographical regions. They are the work of Miss Phyllis Bone, who also furnished for the lintels above the first floor windows smaller round medallions of three animals well known to ancient naturalists, the scarab, the crab, and the octopus.

Throughout the whole building the most emphasised feature is the provision of the maximum amount of light. The museum, which is for teaching purposes,

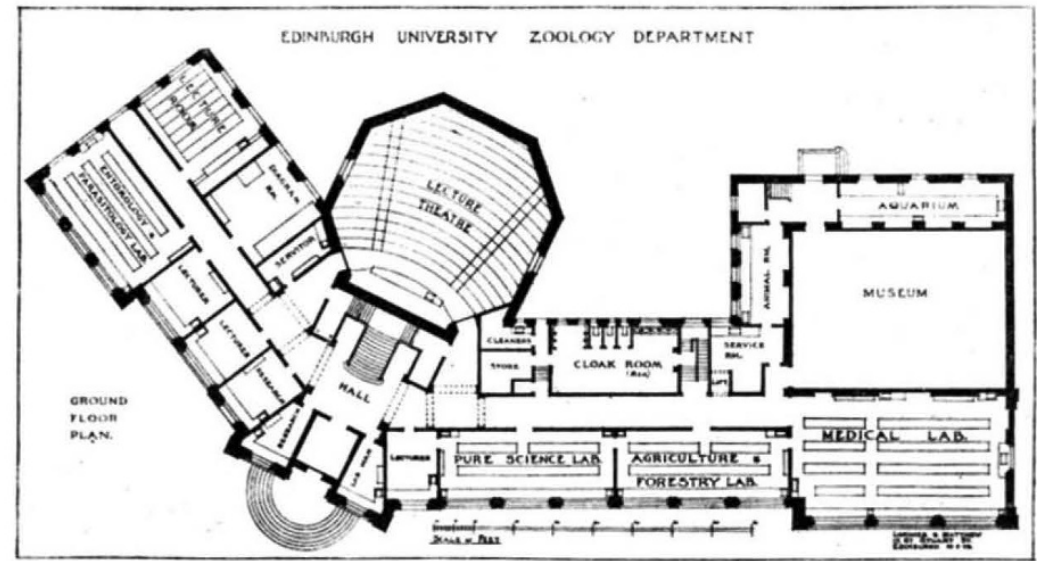

FiG. 2.-Plan of ground floor.

is 55 feet long by 40 feet wide, with a 10 -foot gallery along one of its long sides, under which is a wellequipped aquarium. The main museum is lit by a cupola and the gallery by an oblique roof light, and in both is a new type of glass devised by Sir Herbert Jackson in conjunction with Messrs. Chance. It is designed to exclude the ultra-violet and strong actinic rays, and at the same time provide a maximum transmission and diffusion of direct sunlight. The library is furnished with enamelled steel shelving, gallery, stair, and stack room, and has an initial accommodation of about 8000 volumes, which should 
form an adequate reference collection. The large lecture theatre, occupying most of the central part, is of octagonal form, has a specially constructed diagram screen, and provides 318 separate seats; the two smaller theatres for advanced and post-graduate students each accommodate about 50. The laboratories and research rooms on the two wings are laid out as a series of units 15 feet wide by 16 feet deep, and the inclusion of several units gives laboratories of the sizes required for all the different classes. The Department has, besides the laboratories for the staff, technicians' rooms, workshop, etc., eight separate research rooms each for one worker, and a larger room which would accommodate two to four workers.

The total cost of the building has been $£ 80,000$, and it is felt that with its modern equipment and design it provides adequate facilities for teaching purposes and for the various lines of research that are now being carried on or are likely to be undertaken for some years to come. Two main objects have been kept in the forefront of all the designing; first, fitness for purpose, and secondly, the utilisation of standard units which permit of the maximum amount of interchange and therefore flexibility.

\section{Forest Insurance.}

IN Special Bulletin No. 179 (September 1928), issued by the Experiment Station of the Michigan State College of Agriculture, Mr. Paul A. Herbert discusses "Forest Insurance and its application in Michigan". The greater part of the author's thesis is devoted to the great forest problem in the United States of fires and fire protection, and the consequent higher rates demanded for insurance on forest property exposed, as is the case in America, to this peril. Mr Herbert cites the more or less successful efforts at forest insurance attempted in European countries, which had their origin in France and Germany in 1880 , Norway in 1912, Finland since the Armistice, in Belgium, Holland, Denmark in the late years of last century, and finally in Sweden since 1919.

In treating of ordinary insurance as against insurance against forest fires, the author points out as one of the difficulties that annual returns are not obtainable in the younger stages of a forest, and therefore the private owners of land do not consider that forestry can compete with other productive enterprises. He rightly concludes that the reluctance of landowners to take up forestry as a business undertaking is based mainly on general questions of the risks, the rate of tree growth, and rough calculations as to future costs and prices. It may be admitted that investment in the forestry business will not usually bring in the early returns obtainable from other enterprises, whilst the risks are in some respects greater.

The methods often suggested in order to assist the private landowner to make forestry a paying business are more equitable taxation, government assistance, and better protective methods. These, coupled with an anticipated future increase in the price of timber and other forest produce, would, it is held, make private forestry a paying business. These factors would tend to decrease the cost of production or decrease the risk to which the invested capital is exposed.

On the subject of taxation of woods, the usual remedy suggested is deferred taxation on lands occupied by woods. The chief advantage of this method would lie not in reduced costs, but in reduced risks, and would allow the timber grower to estimate his future taxation in this respect. If any accident happened to the crop or impaired its value the taxes would automatically be reduced. Government assistance, the author considers, should be mainly confined to paying for research work which is beyond the power of the private owner to undertake; whilst the third remedy, protection, involves decreasing the risks and therefore improving the property from an insurance point of view.

The keynote of the author's discussion is the reduction of risk by effective protection, thus facilitating insurance of the property. Such insurance, by eliminating further risks and losses, will place forestry on a business basis. "The capitalist", says Mr. Herbert, "will find the profits obtainable are large enough to be attractive in view of the reduction of uncertainties. The investor will consider the insured forest as sufficient security to warrant lending funds to the business at the usual rate of interest." The whole crux of the business in many countries, both in the past and the present, is bound up with the methods in force in land taxation, which often do not sufficiently distinguish between land from which an annual return is obtainable and that from which the returns are deferred for long periods, as is the case in forestry.

\section{University and Educational Intelligence.}

Cambridge.-Dr. D. Stockdale, fellow of King's College, has been appointed University demonstrator in the Department of Chemistry.

LONDON.-The result of the Convocation elections to the new Senate of the University of London-a general election following the new Statutes-was announced at the meeting of Convocation on May 14. In the Science Faculty there were eleven candidates for five seats, the successful candidates being Dr. C. W. Kimmins with 1018 votes; Prof. F. G. Donnan, 934 ; Sir Philip Magnus, 889; Dr. R. H. Pickard, 847 ; and Mr. G. D. Dunkerley, 835. The unsuccessful candidates were Prof. Winifred Cullis, 806; Dr. G. T. Morgan, 783; Sir Llewellyn Smith, 544; Mr. W. A. W. Dagger, 426 ; Mr. T. Ll. Humberstone, 354 ; and Mr. A. E. Evans, 307. In the Arts Faculty the old members were re-elected, with the addition of Prof. T. P. Nunn. In Engineering, Mr. Roger T. Smith, and in Economics, Dr. W. H. Coates were elected, both being new members of the Senate. The represer atives of faculties include the following:Faculty of Medicine: Lord Dawson of Penn, Dr. H. L. Eason, and Sir Cuthbert S. Wallace; Faculty of Science: Prof. A. J. Allmand, Prof. L. N. G. Filon, Dame Helen Gwynne-Vaughan, and Prof. Frank Horton; Faculty of Engineering: Prof. S. M. Dixon and Prof. E. H. Lamb; Faculty of Economics (including Commerce and Industry) and Political Science: Prof. T. E. G. Gregory.

MANCHester.-Applications are invited for the Edmund Mills Harwood memorial scholarship, value $£ 50$ per annum for three years, at the Manchester Municipal College of Technology. Forms of application and all information are obtainable from the Registrar of the College. The latest date for the return of completed forms is .Tune 15 .

ST. ANDrews.--The University Court has appointed Dr. Frederick Walker, at present assistant in geology, to be a lecturer in geology as from the beginning of the next academical year.

LIKE so many other professions, that of surveying grows more important, complex, and difficult. Old rules of thumb and hastily formed opinions can no longer be applied. If, among the surveyor's essential 